\title{
TROUBLING GENDER EQUALITY: REVISITING GENDER EQUALITY WORK IN THE FAMOUS NORDIC MODEL COUNTRIES
}

\section{Charlotta Edström}

Umeå University

\section{Kristiina Brunila}

University of Helsinki

Email: kristiina.brunila@helsinki.fi

\section{ABSTRACT}

This article concerns gender equality work, that is, those educational and workplace activities that involve the promotion of gender equality. It is based on research conducted in Sweden and Finland, and focuses on the period during which the public sector has become more market-oriented and project-based all over the Nordic countries. The consequences of this development on gender equality work have not yet been thoroughly analysed. Our joint empirical analysis is based on discourse-analytic methodology and two previous empirical studies. By analysing interviews conducted with people involved in gender equality work, this article emphasises the effects of market-oriented and project-based gender equality work in education and working life in Sweden and in Finland. The findings highlight an alliance between projectisation and heteronormativity that acts to regulate how gender equality ought to be talked about in order for its issues to be heard. A persistently constructed 'remedy' to 'the gender equality problem' is that girls and women are positioned as 'needing' to change more than boys and men, by adopting more traditionally 'masculine manners' and choosing to work

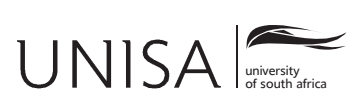

Education as Change www.educationaschange.co.za Volume 20 | Number 1 | 2016 pp.10-27

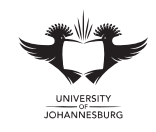

DOI: http://dx.doi.org/10.17159/1947-9417/2016/564 Print ISSN 1682-3206 | Online 1947-9417 (C) 2016 The Authors 
in more 'masculine sectors'. The findings also show that the constitutive forces of these discourses provide little leeway for critical perspectives.

Keywords: gender equality work, labour market interest, marketisation, projectisation, heteronormativity, subjectification

\section{INTRODUCTION}

This article forms a contribution to the discussion on gender equality, a political term that is actualised in demands for various kinds of social change. It focuses on gender equality work, that is, those educational and workplace activities that involve the promotion of gender equality. The article is written in the light of research on gender equality projects in education and in working life that have been implemented in Sweden and in Finland over the past forty years. However, our aim is not to compare gender equality work in different Nordic countries. Instead we want to highlight how gender equality projects in education and in working life in both countries are quite similarly connected with the interests of the labour market, with the demand and supply of labour, and among the market-oriented power relations of working life. In Sweden and in Finland, central government has traditionally supported the responsibilities of their welfare states through specially allocated long-term funding. This has been a benchmark in the Nordic model countries' gender equality work (Bergqvist 1999; Brunila \& Edström 2013). However, publicly and budgetary funded gender equality work has evolved into more market-oriented projects in situations where a project itself has become a new governing mechanism for society. To analyse this trend, we have utilised and developed the concept of projectisation (Brunila 2009). In our article this concept represents a strand of discursive power that intertwines with equality work and content, encompassing subjects that can be known and spoken about and that gain legitimacy from heteronormativity and market-oriented interests. Heteronormativity shortly refers to an understanding of what is labelled heterosexual and masculine as the most valuable, the norm. A critical starting point is that the impact of heteronormativity on gender equality work needs to be problematised and challenged. We will show how, on the one hand, projectisation has contributed to the visibility of problems related to gender equality, while on the other hand it has maintained heteronormativity and the hierarchical order of societal differences, especially of gender, as well as harnessing equality for market use, thereby becoming somewhat useful and productive.

In order to show how projectisation with heternormativity and market-oriented interests permeate gender equality work, we utilise in this article two case examples of gender equality work: one from education and one from working life. At present, when it seems as if projectisation is being applied to its full extent, it is particularly important to recognise that, despite there being a wide range of education and 
working-life contexts in which many equality activities may operate, following the shift to a more project-based perspective, such equality activities tend to have been targeted and shaped by similar forms of power.

The article has the following outline: first, we present the theoretical apparatus, research data and analysis. This is followed by a presentation of findings that begins with a description of the impact the labour market has on gender equality in Sweden and Finland. There then follows a scrutinisation of the Swedish case example of gender equality in education, namely the 'Gender Equality in Preschool' project. This is followed by the Finnish example of gender equality in working life, namely the 'Gender Equality in ICT' project. ICT is used as a shorthand for information and communcation technology. For each case example, the initial focus and its development over time are described, with the main focus of attention being directed at the (in)visibility of labour market interests, projectisation, heteronormativity and subjectification. The article concludes with a discussion.

\section{THEORETICAL APPARATUS}

The meaning of gender equality is not written in tablets of stone. Instead, different gender equality 'diagnoses' (Bacchi 2009) and 'remedies' are at play. The meanings assigned to the concept influence objectives and the ways these are to be pursued. A common starting point when writing this article is that we consider it vital that meanings of gender equality address current heteronormative power relations. Previous studies (Brunila et al. 2005; Brunila 2009; Lehtonen 2010) indicate that heteronormativity is a crucial obstacle to the advancement of a gender equality that moves beyond the notion that girls and women need to change more than boys and men. There is a clear need to 'trouble' this. The notion of 'troubling' is used in this article in two ways. Firstly, our focus is on gender equality projects that are considered as 'troubling' because of their aim in promoting especially women's positions in education and in working life. Secondly, we aim to 'trouble' the projectoriented practices regarding gender equality work (Butler 1990; Youdell 2011) that reproduce problems from the perspective of women's positions in education and in working life.

Since Sweden and Finland entered the European Union, research has increasingly favoured a reliance on project-based activities in the public sector (e.g., Brunila 2009; Brunila \& Ylöstalo 2013; Hansson \& Lundahl 2004; Sjöblom 2009). Such an increased favouring of these types of projects forms part of a larger societal and market-oriented shift that has created a site in which to mix public and private interests. Short-term, publicly funded projects have become a common solution to all types of problems so that such projects have become a common way to implement many welfare policies, including gender equality (Guðbjörnsdóttir 2010; Lundahl 2002; Pinqus \& Van der Ross 2001; Rantala \& Sulkunen 2006). Since the 1970s 
most gender equality work in education has been carried out through publicly funded projects (e.g., Brunila 2009; 2011; Edström 2010; SOU 2010:83; Tallberg Broman 2002). This has included the distribution of funds from, for example, state ministries and agencies, national associations of municipalities and regions, municipalities, unions and foundations. The state has had, as mentioned above, a pivotal role in this process. Taking Sweden as an example, a main theme over this time has been the allocation of resources to the running of summer courses in technology and science for lower secondary girls (Edström 2005; Tallberg Broman 2002). In the mid-1990s, by which time these courses had been conducted in most Swedish municipalities, this strong emphasis began to be questioned by the state itself (Prop 1994/95:164); nevertheless, this focus remains almost twenty years later. There has been a similar situation in Finland where girls and women have been guided and trained in the ICT field for decades by the government (Vehviläinen \& Brunila 2007). Developments in state governance with respect to gender equality in education in the $21^{\text {st }}$ century have been characterised not only by time-limited work, but also by gender equality becoming a clearer element of new ordinary governance processes such as audits and evaluations (Brunila \& Edström 2013). However, considering the increased favouring of projects as being the solution to different perceived problems, the preconditions for continuing with projects have definitely improved (Brunila \& Edström 2013).

New governance is a market-oriented attempt to introduce territorially unbounded public and private actors, operating outside of their formal jurisdictions, into the decision-making processes of political institutions (c.f. Bailey 2006). Projects, as a form of new governance, work by creating a project society (Brunila 2009; 2011; Rantala \& Sulkunen 2006) with a level of interdependency among individuals, groups, organisations, enterprises, officials and the state, in order to solve the problems of welfare politics by market-oriented and project-based interventions. In addition to new governance, projects represent a form of governmentality (Dean 1999) because they link the constitution of individuals more closely to the formation of the state, and to shaping the action of subjects (Rantala \& Sulkunen 2006). As organised practices through which individuals are governed (Rose 1999), projects extend marketisation even further into practices as a form of governmentality. Marketisation in this paper is referred to a situation when several producers compete over public tasks and/or when internal steering systems are developed with the market and industry as models. We use the term to denote the direction of the change process, and quasi-markets when referring to the resulting situation as this is not a market in the strict sense. In contrast to proper markets, quasi-markets are characterized by being established and controlled by the state (Lundahl et al. 2013). Earlier research concerning projects has shown that the project has become an ideological method with which to bring in more market orientation (e.g. Rantala \& Sulkunen 2006; Sjöblom 2009; Vehviläinen $\&$ Brunila 2007). A significant proportion of domestic funds have been directed towards projects that specifically reflect EU policies (Bache 1998; Sjöblom 2009). 
In exploring the discourses of project-based gender equality work there is a need to explore the ways in which certain elements of the discourse have become more powerful than others. Although gender equality in the $21^{\text {st }}$ century also has become a clearer element in new ordinary governance, project-based activities seem to represent what society and the state largely has to offer for gender equality (Brunila \& Edström 2013). The study of the power-relations that affect people associated with gender equality work is pivotal, because power-relations have important material effects on people's lives. Such studies involve an examination of the use of discursive power. In order to grasp and acknowledge the forms of power that shape equality work, we have utilized the concept of projectisation. As a form of discursive power, projectisation is important to analyse because it is tolerable only on condition that it masks a substantial part of itself. It teaches project participants, workers, and other people involved: how to present themselves in the right way; how to learn to make their own choices and carry their own individual responsibilities; how to learn to become developmental and trainable. Crucially, it also elicits the self as a subject to be known and talked about by oneself and others. Projectisation would not have succeeded without heteronormativity. Heteronormativity carries the idea of a hierarchical gender order. It means a code of behaviour that expects women to behave in a less valued 'feminine' manner, and men in a more valued 'masculine' manner (see more in detail Butler 1997; Lehtonen 2010). The perception of genders as two inherently different beings has resulted in comparisons and juxtapositions. We will also show how this has appeared to be an obstacle to gender equality work.

\section{Research data and analysis}

Both authors share a critical interest in gender equality in education as well as a history of gender equality work: Author 1 is Swedish with a background in preschool education and political sciences; Author 2 is Finnish with a background in politics and sociology of education and adult education. During our initial discussions about our respective fields of research and main interests, we realised that even though we have been involved in different forms of gender equality work in various parts of education and the labour market, our data and experiences as researchers were surprisingly similar. We therefore bring our previously gathered empirical data from each of our respective studies together in the present article.

This joint analysis has also made us critically examine marketisation and projectisation as well as our own previous activities in equality projects and equality work (see also Brunila et al. 2005). The observation that gender equality work does not necessarily always have anything to do with gender equality has been useful. It might be tempting to start teaching others, to dress up as an expert, but taking gender equality into consideration in your own activities calls for constant negotiation, which does not necessarily prove easy. 
Author 1 collected data from three preschool settings, which were all part of the same major Swedish gender equality project in education, here referred to as the 'Gender Equality in Preschool' project. This county-wide, time-limited, state-funded project, which ran for two years at the beginning of the $21^{\text {st }}$ century, was provided with economic resources by a state delegation that was also time-limited. The actors involved in the project included, among others, the local authority association, the county council, a university, and a network with participating preschools from more than ten municipalities. The aim of the project, which included about 300 participants, was to increase knowledge about gender equality, to provide methods and tools, and to contribute towards the distribution of knowledge. Participation included lectures, seminars and supervision. Author 1's main data include the results of interviews with nine project participants, preschool teachers and nursery assistants from three preschools. This is complemented with field-notes from the interviews and documentation from the county-wide project and the three preschools.

Author 2 collected data from over 100 gender equality projects that have operated in education and in working life; she has been directly involved in several of these projects herself. In this article she has chosen to utilise data that have been mainly gathered from one equality project, here called the 'Gender Equality in ICT' project, which has operated in working life and in several private companies in the metropolitan area of Finland. She studied the project for two years and produced data by interviewing both project workers and project participants, including project workers from four small- and medium-sized ICT companies; altogether there were 24 interviewees. She also wrote a research diary. The aim of the project was to promote gender equality and desegregation in working life and especially in the ICT sector. The project operated during the 2000s for two years. The reasons why these two projects were chosen were partly that, in line with the reasoning about new governance and project society, they both involve a wide number of actors, and partly, as we will illustrate throughout the findings, because they represent typical heteronormative and market-influenced approaches related to gender equality in education and working life in general.

In the analysis in this article, we have adopted a discursive approach that emphasises the analysis of power inherent in the projectisation of equality work. Projectisation is a disciplinary and productive form of discursive power and the notion is derived primarily from the work of Michel Foucault. Projectisation combines the ideas of new governance and governmentality. As a form of new governance, it represents market-oriented, managerialist, self-organising networks, and by incorporating, producing and positioning everyone involved with projectbased work, it represents a form of governmentality. We study the practices relating to project-based gender equality work in terms of discursive power, by acknowledging the relationships among knowledge, discourse and power as being productive and regulative (Foucault 1976; 1991; Davies 1998). Projectisation is both compelling and 
rewarding because it defines a cultural script about appropriate responses to events, and a set of associated practices through which people make sense of themselves and others. It helps to create individuals involved in equality work, not only as objects but also as subjects, due to the way in which they can also influence the individual's sense of self.

Furthermore, we have included the idea of subjectification (Davies 1998) within the concept of projectisation. Projectisation as a form of subjectification describes the ongoing process whereby one is placed and takes place in the market-oriented and heteronormative discourse. Through those discourses, people become speaking subjects at the same time as they are subjected to the constitutive force of those discourses. Such an approach allows one to see how the forms of power work, and to see the effects that they have on forming how one must speak in equality work in order to be heard, and how certain discursive constructions are appropriated, while others are discarded as irrelevant or even threatening. This enables us to study the ambivalent process of simultaneous submission and mastery of the project-based equality work and what consequences this has. It presents an opportunity to explore the possibility of speaking and acting otherwise, through the process of submitting to and mastering the discourse. This is by no means an easy process. The process of submitting and mastering means tensions and anxieties that were often reflected during the interviews.

From the perspective of subjectification, it is the very constitutivity of the subject that enables people involved in equality work to act in these forms of power, which are not just regulating but also productive. Therefore, it is crucial to acknowledge the critical perspectives related to the gender equality discourse. Critical perspectives offer ways of seeing and thinking about equality work as a possibility for an alternative discourse. However, as Davies, Dormer, Gannon, Laws and Rocco (2001) suggest, this demands one to be conscious of, and to have mastery of the discourse one desires in order to be critical of it and to resist being channelled into an undesired discourse. Only then can there be space for seeing, thinking and acting otherwise.

In addition, we consider that projectisation as a form of discursive power is always being constructed and is never fixed. In equality work, at any moment in time and space, a range of competing discourses exist (Bacchi 2009), some of which are given more space than others. Power is thus exercised in and through discourses. Therefore, we argue that by making visible the ways in which equality work is constructed, these 'self-evident truths' can be challenged. In short, in the actual re-reading of our respective previous empirical studies on gender equality, we have focused on the (in)visibility of labour market interests and marketisation, projectisation and heteronormativity, including subjectification and submission and mastery of the discourse. This includes scrutinising the attention on individuals, groups and on variations within groups, including intersections. The main focus of 
attention in the re-reading and in the presentation of results has been on identifying, scrutinising and problematising similar themes. Consequently, although there definitly are clear differences between the two scrutinised projects (for example one concentrates on gender equality for very young children, while the other concentrates on gender equality for adults), it is the similarities that are brought to the fore.

\section{THE IMPACT OF THE LABOUR MARKET - A NEVER-ENDING STORY?}

In both Sweden and Finland, as in the other Nordic countries, gender equality policy is mainly targeted to working life, although there has also been a number of gender equality projects in the educational field. Gender equality in working life is, in both countries, regulated by legislation covering public and private sectors and involves, for example, requirements concerning gender equality or equal treatment plans or and having employees in charge of promoting these issues. Gender equality work in working life takes varying forms depending on, for example, who is doing it and the financial resources devoted to it (Ylöstalo 2012; Brunila \& Ylöstalo 2013). The main part of the Swedish and Finnish work has, as in the other Nordic countries, been targeted at improving girls' and women's conditions in the future or current labour market by making them more similar to those of men.

Though the scope has widened over the years, the main emphasis on women in the labour market has remained unchallenged. Special attention has been directed at increasing the proportion of women in traditionally male-dominated areas such as mathematics, natural sciences and technology. Over the years, attention has also been directed at employing more men in sectors where women have traditionally constituted (and still do) the large majority of the workforce, for example, in preschool and in the early years of compulsory school, though this emphasis has not been given attention equivalent to that given to changing girls' and women's choices. The increased market influence has meant that the traditional 'Nordic' focus on gender equality as a labour market issue connected to equality, democracy and social justice, at least in Sweden and Finland, seems to be increasingly matched by arguments that gender equality in education may increase competitive advantages (Brunila \& Edström 2013). In recent years, more attention than before has also been focused on what has been described as 'boys' underachievement' (Arnot, David \& Weiner 1999; Arnesen, Lahelma \& Öhrn 2008; Francis \& Skelton 2005). Although the labour market is still at the centre of the arguments concerning why gender equality 'needs' to be pursued, the arguments include partly competing discourses, although they do not necessarily have to contradict one another.

One era making its mark on the definition of gender equality and its objectives has been the European Union (EU) policy-making period: a time marked by the emergence of new forms of governance (Outshoorn \& Kantola 2007). The Nordic 
countries constitute a special forum for equality policies within the EU. When Sweden and Finland joined the EU in 1995, high expectations were placed on them with regard to equality issues. Nevertheless, both countries were advised by the EU to consider the reasons for gender segregation in the labour market and to explore ways of dissolving it. In both countries, EU structural funds among national funders (such as ministries) have been a nationally significant source of funding for projects aimed at labour market desegregation. Generally speaking, the number of different projects has increased in parallel with an increase in the availability of project funding opportunities. However, this cannot be regarded as a direct increase in resources but rather as an EU-driven financial and administrative incentive, since funds paid to the EU are directed through structural funds into various projects (Brunila et al. 2005). Although it is making its mark on definitions of gender equality, EU membership has seemingly affected different parts of education to various degrees, in particular by having less impact on early years education than on later education. Although other issues are touched upon to some extent, the overall EU policy in the field of gender equality seems to be rather biased towards issues within the labour market. The main focus of EU gender equality policy has been on women as a group, including the promotion of an efficiency discourse that tries to fit social arguments into economic arguments (Calvo 2013). Listed below are some examples of the vast number of EU-funded Finnish gender equality projects directed towards women in the labour market:

- Utilising Women's Competences in the Field of Technology.

- Female Energy to the Transportation Business.

- The Clatter of High Heels to the Transportation Business.

- Women in Industry and Technology. (Examples of Finnish project titles in the 2000s)

Some of these project titles simply demonstrate some of those sexist discursive constructions caused by heteronormativity and its narrow view of women. Furthermore they also demonstrate how the equality obligation laid down in EU structural policy as a mainstreaming principle has been interpreted in practice by specifically directing actions towards women, rather than integrating equality in all activities. This has been the case in both Sweden and Finland (SOU 2005:66). Taking Finland as an example, one consequence has been that many projects implemented in education and in working life after the mid-1990s were specified as so-called women's projects, aimed at fitting women in to existing structures, rather than challenging the structures themselves. Gender equality work funded by the EU has mainly focused on changing girls' and women's educational and career choices, and on the integration of ICT into teaching. The projects have developed new methods and practices to shape girls' and women's attention and interest in 
technology, including job training programmes to increase women's competencies in technology (see also Brunila 2009; Vehviläinen \& Brunila 2007). Accordingly, in project-based gender equality work women have been perceived as gendered beings whose characteristics have been assessed in relation to labour market needs.

\section{THE EXAMPLE OF GENDER EQUALITY IN EDUCATION: THE GENDER EQUALITY IN PRESCHOOL PROJECT}

In this section, we present a Swedish case example of gender equality in education: the Gender Equality in Preschool project. We include a scrutinisation of the (in) visibility of labour market interests, projectisation and heteronormativity, including subjectification and submission and mastery of the discourse. The discussions, both within the county-wide project and at the three preschools, mainly focus on gender relations, and on girls and boys alone. There is little mention of intersections. This rather narrow focus, which seems to have been prevalent throughout the whole project, is also visible more widely in the gender equality work in Swedish preschools (C. Edström, in progress). Gender equality is mainly constructed as a delimited preschool issue that concerns, first and foremost, the approach and language used by preschool teachers and nursery assistants towards girls and boys, although some consideration is also given to its relevance to future education and the labour market. The participants' attention on the future mostly concerns the (positive) preschool influence on the future public sphere. Below, we quote one example of a participant arguing that gender should not matter in a child's consideration of its choice of future occupation:

Yes. Exactly this that one should provide every child with opportunities based on person, irrespective of gender .... I should be able to choose what I want to do irrespective of if I am a girl or if I am a boy. I mean, am I a girl who wants to be a construction worker. Yes, well then I should be able to become that. And am I a boy who wants to be a ballet dancer. Yes, well then I should be able to become that .... Gender should not be decisive for my choice in the future (Interview project participant 2007).

On the one hand, it may be argued that rather few discussions concern future education or the future labour market. On the other hand, it is noteworthy that there is emphasis placed on the labour market, considering that the oldest children in preschool are five-years old for whom it will be at least ten years, probably more, before they actually constitute part of the workforce. What we want to 'trouble' here is not the focus on the labour market in itself, but rather that very little is mentioned about the future private sphere. It seems that the impact of labour market interests has some significance already on constructions of gender equality in preschool.

What then, are the discourses underlying the project participants' discussions? The project participants' reasoning includes some attention on preschool children as individual, but there is overall stronger emphasis on girls and boys as homogeneous, 
oppositional groups. That (all) boys are considered to have acted in one way and (all) girls in another way before the gender equality work has begun is visible and is exemplified in the following example where the children's previous behaviour during lunchtime is described:

Because before [the gender equality work] we thought they only screamed, the boys, like: "We want! Bring me!", for example, jam; and the girls have, like, been lip-reading and almost directly understood what they [the boys] have meant and they have most often given [it to] the boys (Interview project participant 2007).

The impact of discursive power relations and projectisation is clear in this and in a number of other examples from the interviews with project participants. For example, the above excerpt, where acknowledgement of variations within groups are missing, might just as well have been selected directly from one of the main books used in the wider project. The participants position themselves, the children and their gender equality work in relation to the wider project. Overall, throughout the discussions in the three preschools, the girls' group is encouraged to be stronger, braver, more independent and to take more space, while the boys' group is encouraged to be more socially and linguistically competent. Heteronormativity is visible both in the positioning of children as two oppositional groups and in the sense that the girls' group is to be changed, rather subtly, a bit more than the boys' group. In addition, the desired notion of a more gender equal girl is rather similar to that of a tomboy, whereas the notion of girls taking up traditional girlish positions, that is, dressing in pink skirts and dresses, is constructed as the 'least wanted' stereotype in gender equality work (C. Edström 2010, in progress). This seems clearly linked to heteronormativity and to discourses that prescribe what is desirable and recognisable as an acceptable form of subjectivity (Davies et al. 2001). When describing the actual work with the children, where the participants repeatedly refer to the wider project, their more nuanced reasoning that involves some attention being directed on children as individuals, on variations within groups, and on intersections between gender and age, 'lose out' to the 'project methods'. This may be understood in terms of subjectification.

Issues that can be related to marketisation, such as the presentation of gender equality work in different contexts and the support this gets from the principal and local authorities, are also brought forward in the three preschools. What cannot be said to parents is also discussed, especially in the most explicitly feminist preschool where some terms, such as 'feminism' and 'gender equality' were initially avoided in order to avoid discussions with parents about 'changing their boys into girls' and to avoid being perceived as 'militant' or 'scary'. This may be understood as if the participants are made speaking subjects at the same time as they are subjected to the discourses' constitutive force. 
Much of the work in preschools seems to involve submission to the wider project, but there are also examples that may be considered to open up possibilities for alternative discourses. Although the overall influence of heteronormativity is discernible, boys taking up traditional female positions are, in some of the participant examples, recognised as acceptable forms of subjectivities (Davies et al. 2001). Although referred to in current societal structures, it is still argued that preschool boys should in any case be provided with opportunities to play with Barbie dolls and, as in one of the examples above, allowed to choose traditionally strongly female coded future occupations, such as becoming a ballet dancer (cf. Lindqvist 2010). Although the binary construction of girls and boys not is challenged, there seems to be some resistance against the higher valuing of 'masculine' manners. Still, although there is some resistance, this is not the main pattern. Instead, put together, the repeatedly constructed 'remedy' to 'gender equality problems' in this example seems to involve that girls 'need' to 'change a bit more'.

\section{THE EXAMPLE OF GENDER EQUALITY WORK IN WORKING-LIFE: THE GENDER EQUALITY IN ICT PROJECT}

The alliance of projectisation, marketisation and heteronormativity also seems quite strong in gender equality work in working life. Despite a starting point that has a wide perspective, the focus of projects easily ends up changing women and their educational or career choices towards male-dominated branches. The Gender Equality in ICT project is a typical example of this. It started with a wider perspective that acknowledged societal differences such as gender, age, cultural background, health, sexual orientation and religion together:

In the project ... understanding of gender and other societal differences related to gender such as age, cultural background, health, sexual orientation and religion is deepened (Extract from a project leaflet 2005).

Furthermore, the group interviews showed that the people involved in equality work also wanted to include other differences in their equality planning:

Participant 1: The [Gender] Equality plan should not focus only on differences between genders. We have different nationalities, for example here we have... are there twenty people?

Participant 2: Yes, something like that.

Participant 1: Ok, then we can say that $10 \%$ of staff are from a different background than Finnish, I think we should also acknowledge this in our equality plan. (Extract from group interview 2004) 
Nevertheless, the end result was that the guidebook that was produced, based on the project-based equality work conducted in the companies, was focused on attracting women to the technology field:

The ICT-branch wants to attract more women. It is time to change the traditional preconceptions about this branch not being suitable for women ....) Development of equality can be important for the company in the competition for new and competent workers (Extract from the project guidebook 2007).

The change in the discourse that took place in the Gender Equality in ICT project, and which resulted in a narrow focus on women and technology only, occurred within a period of just two years.

The labour market has undergone a major change in the past twenty years. There is a great variation in the terms and conditions of paid work, and different types of fixed-term and temporary employment have been common. Such contracts are increasingly common among young, well-educated women who are often the target of equality project activities (Brunila et al. 2005). This might explain how women in these projects as well as at the labour market have been systematically treated as a flexible and cheap labour force. The alliance of marketisation and projectisation has avoided acknowledging that societal differences should be recognised as a system of oppression, or as being intersectional.

Futhermore, this tells something about the difficulties that gender equality work has had in the heteronormative discourse. Gender equality projects have systematically aimed at the more valuable, male-centred environment towards which women are 'encouraged' (see also Brunila 2009). These heteronormative discourses help producing ways of being and doing suitable for each gender as well as different opportunities for action. This is how gendered working life is formed and reproduced.

The Gender Equality in ICT project was a sub-project of a larger EU-funded project that held regular research meetings for all the researchers working on the whole project. Author 2 also participated at these meetings both as a listener and as a speaker. On one occasion she was offered a chance to speak about the project on which she was working as a researcher. Here is an example of her research diary from this research meeting:

I spoke about some ways that other gender equality projects have previously acknowledged heteronormativity in their activities. One researcher from the audience raised his hand and asked "Why do we have to talk about this so much because isn't the majority still heteros?" I asked who he referred to by "us". The researcher looked around and replied, "Well, us" (Extract from Author 2's research diary 2006).

Heteronormativity is so obvious in gender equality work that in many instances critical perspectives towards it just do not get heard. In project-based equality work, people end up producing and implementing heteronormativity often without even realising it. Other examples of heteronormativity were mentioned in some interviews 
that Author 2 conducted with gender equality work specialists. These interviews showed how heteronormativity shaped activities. One of the equality specialists, who had conducted several ICT and equality projects in working life, commented how women in these projects are often positioned as targets. She wondered: 'To what extent are they there as actors?' Another gender equality specialist who has worked in several working life equality projects explained the possibilities for negotiations as follows:

They [the evaluators] had written that the objective of the project is to bring more women into the field of technology. I then said that bringing women into technology has never existed in the project plan. In my mind it has not been the aim of the project. The evaluator, however, continued arguing that it was the goal. This is very contradictory (Interview with Equality specialist 2004).

The interviewed specialists are competent promoters of gender equality. However, they need to negotiate their aims, for example, in order to get funding, with actors who have little knowledge concerning the social construction of gender, equality and/or ICT.

All these examples above show how marketisation, projectisation and heteronormativity work in practice. Regardless of several objections, the result is that the activities are ultimately aimed at changing women's career choices, especially with respect to the field of technology (see also Vehviläinen \& Brunila 2007). As a consequence, the heteronormative gender hierarchy, as well as the difference in value between the environments of the two genders, persists as long as activities are aimed at the more valuable male-centred environment that women are being directed towards.

An understanding is needed of how marketisation, projectisation and heteronormativity as discursive power relations function as a forcible framework within which the subject and action are formed. We would also point out that the decision to focus on girls and women in these projects, as in so many other projects, stems not so much from the individual, but from the condition of gendered possibility - the discourses that prescribe not only what is desirable, but what is recognisable as an acceptable form of subjectivity (Davies et al. 2001).

\section{CONCLUDING DISCUSSION}

This article has 'troubled' gender equality projects in education and working life in two of the famous Nordic model countries, Sweden and Finland, at the beginning of the $21^{\text {st }}$ century. It has illustrated how gender equality work is connected in similar ways with the interests of the labour market, the demand and supply of labour, as well as with the market-oriented power relations of working life. Taking examples that ranged from the early years of education right up to the labour market, we have scrutinised how project-oriented practices regarding gender equality work 
(Butler 1990; Youdell 2011) are permeated by the reproduction of problems from the perspective of girls' and women's position in education and in working life. We have suggested that project work, however well-intended, is a setting/situation where girls and women, from their childhood, over and over again, learn to position themselves and are positioned as a potential and mobile labour force. More valued heteronormative 'masculine' manners are repeatedly presented as ideals that help one to assert oneself in current or future education and in labour markets, especially in those sectors where men have traditionally constituted the majority of the labour force and are considered to be the most important. The 'need' for more 'masculine' manners and sectors in the renowned Nordic model countries' gender equality work, definitely needs to be problematised further.

Our analysis of gender equality projects operating in education and working life shows that marketisation, projectisation and heteronormativity have enrolled a circle by benefiting one another and regulating how equality ought to be talked about in order for it to be heard. There are some differences between the examples that we have presented; for example, that the attention to more 'boyish' or 'masculine' manners is clearly already present in preschool and beyond, whereas the emphasis on the labour market and especially on science and technology becomes stronger only later on. Nevertheless, when taking these differences into consideration, the examples clearly illustrate the influence of marketisation, heteronormativity and projectisation where a persistently constructed 'remedy' to the 'gender equality problem' is that girls and women 'need' to change a bit more.

Some of our examples also illustrate that the people involved in project-based equality work have been quite critical towards activities targeted at girls and women. We have talked about the assumptions of differing characteristics that lead to different treatment, which then produces differences that strengthen the assumption of gender-bound characteristics. For example, one project worker commented that women in these projects are usually positioned as targets. She wondered: 'To what extent are they there as actors?' Project-based gender equality work does not seem to offer much space for such critical perspectives to be heard because of prevailing norms and conflicting power relations.

However, being able to write about equality work as a diverse and complex area will hopefully encourage readers to begin asking more critical questions. Talking with people involved in equality work has encouraged the finding of a way in which to analyse equality work as sites of constant negotiations. This has enabled us to see that problems concerning equality are not objects, but rather the products of different practices, and are therefore always negotiable and changeable. A significant amount of equality work has been done by switching and shifting from one discourse to another depending on the political situation and the various societal interests. People involved in gender equality work may need to be pragmatic (Weiner 2006) and, due to current global marketisation, increasingly to demonstrate the impacts of 
their work in market-oriented terms. This may be considered an obstacle, but when different discourses are utilised, equality work becomes more possible in contexts that might otherwise be inaccessible.

And despite this, there will be occasional setback, and they're always pretty depressing. But then you have to think again what to do, and what you can learn from this, so that the same thing won't happen again the next time (Interview with equality specialist 2004).

It is important to highlight that gender equality work is also a personal process of change for those involved. Its consequences may also be surprising but it is not necessarily an easy process. The impacts of personal change also extend outside the actual project. Evaluating those impacts as part of the project results is difficult if not impossible (Brunila et al. 2005).

\section{REFERENCES}

Arnesen, A., Lahelma, E. \& Öhrn, E. 2008. Travelling discourses on gender and education: The case of boys' underachievement. Nordisk Pedagogik 28(1):1-14.

Arnot, M., David, M. \& Weiner, G. 1999. Closing the gender gap: Postwar education and social change. Cambridge: Polity Press.

Bacchi, C.L. 2009. Analysing policy: what's the problem represented to be?. Frenchs Forest: N.S.W: Pearson.

Bache, I. 1998. The politics of European Union regional policy: Multi-level governance or flexible gate keeping?. Sheffield: UACES/Sheffield Academic Press.

Bailey, D. 2006. Governance or the crisis of governmentality? Applying critical state theory at the European level. Journal of European Public Policy 13(1):16-33.

Bergqvist, C. (Ed.) 1999. Likestilte demokratier?: Kjønn og politikk i Norden. Oslo: Universitetsförlaget.

Brunila, K., Heikkinen, M. \& Hynninen, P. 2005. Difficult but doable. Good practices for equality work. Oulo University: Kajaani University Consortium, Adult Education Unit/The National Thematic Network.

Brunila, K. 2009. PARASTA ENNEN. Tasa-arvotyön projektitapaistuminen. Helsinki: Yliopistopaino.

Brunila, K. 2011. The projectisation, marketisation and therapisation of education. European Educational Research Journal 10(3):425-437.

Brunila, K. \& Edström, C. 2013. The famous Nordic gender equality. What's 'Nordic' about it? Nordic Studies in Education, 33(4), 300 - 313.

Brunila, K. \& Ylöstalo, H. 2013. Challenging gender inequalities in education and in working life - a mission possible? E-publication ahead of print. Journal of Education and Work.

Butler, J. 1990. Gender trouble. Feminism and the subversion of identity. New York: Routledge.

Butler, J. 1997. Excitable speech: A politics of the performative. London: Routledge. 
Butler, J. 2008. 'An account of oneself'. In Judith Butler in conversation. Analyzing the texts and talk of everyday life, B. Davies (Ed.), 19-38. London: Routledge.

Calvo, D. 2013. What is the problem of gender?:Mainstreaming gender in migration and development policies in the European Union. Göteborg: Göteborgs universitet,institutionen för sociology och arbetsvetenskap.

Davies, B. 1998. A body of writing 1990-1999. Walnut Creek, CA: AltaMira Press.

Davies, B., Dormer, S., Gannon, S., Laws, C. \& Rocco, S. 2001. Becoming schoolgirls: The ambivalent project of subjectification. Gender and Education 13(2):167-182.

Dean, M. 1999. Governmentality: Power and rule in modern society. London: Sage.

Edström, C. 2005. Is there more than just symbolic statements? Gender equality as part of Swedish state educational politics Tidskrift för lärarutbildning och forskning 3(4):103-130.

Edström, C. 2010. Samma, lika, alla är unika. Jämställdhet i förskolepolitik och praktik. Umeå: Umeå University.

Edström, C. (In preparation). Pedagogues' constructions of gender equality in selected Swedish preschools: A qualitative study. Education Inquiry 5(3).

Foucault, M. 1976/1990. The history of sexuality, vol. 1: An introduction. New York: Pantheon Books.

Foucault, M. 1991. Discipline and punish. The birth of the prison. London: Penguin.

Francis, B. \& Skelton, C. 2005. Reassessing gender and achievement: Questioning contemporary key debates. London: Routledge.

Guðbjörnsdóttir, G. 2010. Gender in teacher training in Iceland. Paper presented at the European Conference on Educational Research (ECER) Symposium: Gender and sexualities in teacher training and higher education, Helsinki, Finland.

Hansson, K. \& Lundahl, L. 2004. Youth politics and local constructions of youth. British Journal of Sociology of Education 25(2):161-178.

Hultqvist, K. \& Dahlberg, G. (Eds.) 2001. Governing the child in the new millennium. New York: RoutledgeFalmer.

Ikävalko, E. \& Brunila, K. 2011. Tasa-arvosuunnittelu managerialistisen hallinnan tekniikkana Sosiologia 48(4):323-337.

Interview with equality specialist. 2004.

Interview. Group interview. 2004.

Interviews with project participants 2007

Lehtonen, J. 2010. Gendered post-compulsory educational choices of non-heterosexual youth. European Educational Research Journal 9(2):177-191.

Lindqvist, A. 2010. Dans i skolan - om genus, kropp och uttryck. Umeå: Umeå universitet. Institutionen för estetiska ämnen.

Lundahl, L., Arreman, Erixon, I., Holm, A-S. \& Lundström, U. 2013. Educational marketization the Swedish way. Education Inquiry 4(3):177-191.

Lundahl, L. 2002. Local youth projects: Political rhetoric and strategies. Social Policy and Society 1(3):247-255.

Outshoorn, J. \& Kantola, J. 2007. Changing state feminism. Basingstoke: Palgrave Macmillan. 
Pincus, I. \& Van der Ross, J. 2001. Valtiot, kunnat, tasa-arvo ja poliittinen tahto. In Tasa-arvoiset demokratiat? Sukupuoli ja politiikka Pohjoismaissa, C. Bergqvist (Ed.), 221-244. Helsinki: Edita.

Project leaflet. 2005.

Project guide book. 2007.

Regeringens proposition 1994/95:164. Jämställdhet mellan kvinnor och män inom utbildningsområdet.

Rantala, K. \& Sulkunen, P. (Eds.) 2006. Projektiyhteiskunnan kääntöpuolia. Tampere: TammerPaino.

Research diary. 2006.

Rose, N. 1999. Governing the soul. The shaping of the private self. London: Free Association Books.

Sjöblom, S. 2009. Administrative short-termism: A non-issue in environmental and regional governance. Journal of Environmental Policy and Planning 11(3):165-168.

Swedish government. 1995. Government bill. Jämställdhet mellan kvinnor och män inom utbildningsområdet. 1994/95:164.

Swedish state investigation. 2005. Makt att forma samhället och sitt eget liv. SOU 2005:66.

Swedish state investigation. 2010. Att bli medveten och förändra sitt förhållningssätt jämställdhetsarbete i skolan. SOU 2010:83.

Tallberg Broman, I. 2002. Pedagogiskt arbete och kön: med historiska och nutida exempel. Lund: Studentlitteratur.

Vehviläinen, M. \& Brunila, K. 2007. Cartography of Gender Equality Projects in ICT. Liberal equality from the perspective of situated equality. Information, Communication \& Society 10(3):384-403.

Weiner, G. 2006. Out of the ruins: Feminist pedagogy in recovery. In The SAGE Handbook of Gender and Education, C. Skelton, B. Francis, C. Smulyan (Eds.), 79-92. London: SAGE.

Ylöstalo, H. 2012. Tasa-arvotyön tasa-arvot. Tampere: Tampere University Press.

Youdell, D. 2011. School trouble. Identity, power and politics in education. London: Routledge. 